\title{
Oral anticoagulants for the treatment of venous thromboembolism and non-valvular atrial fibrillation: a cost analysis
}

\author{
Isabella Cristina DENARDIN ${ }^{1}$ (D), Helena Hiemisch BORBA ${ }^{1}$ (D), Antônio Matoso MENDES ${ }^{1}$ (iD \\ ${ }^{1}$ Complexo Hospital de Clínicas - Universidade Federal do Paraná \\ Corresponding author: Denardin IC, isabellacdenardin@gmail.com \\ Submitted: 12-02-2021 Resubmitted: 07-03-2021 Accepted: 08-03-2021 \\ Peer review: Carine Raquel Blatt and Gabriel Freitas Rodrigues
}

\begin{abstract}
Objective: To analyze the total direct cost of anticoagulant therapies indicated for the chronic treatment of patients with non-valvular atrial fibrillation (AF) and the acute treatment of venous thromboembolism (VTE) in the perspective of a tertiary teaching hospital and the national public health system. Methods: Therefore, the review of the treatment regimens that included all the oral anticoagulants based on nationals and internationals guidelines. The cost data were extracted and performed the simulation of the costs of pharmacological therapy and exams for monitoring therapeutic goals. The time horizon was defined by 365 days for AF and 90 days for TEV. Results: The treatment cost of 90 days in VTE was: rivaroxaban (USD \$82,96 to USD \$156,15), apixaban (USD \$110,25 to USD \$123,11), edoxaban (USD \$106,56 to USD \$265,15), dabigatran (USD \$150,71 to USD \$249,98) and warfarin (USD \$54,94 to USD \$159,66). While the treatment cost of AF was: rivaroxaban (USD \$270,35 to USD \$508,89), apixaban (USD \$414,86 to USD \$463,26), edoxaban (USD \$402,41 to USD \$477,78), dabigatran (USD \$414,86 to USD \$416,24) and warfarin (USD \$20,03 to USD \$43,54). Conclusion: Warfarin presented the lowest treatment cost for both comorbidities. However, although direct oral anticoagulants (DOACs) are always associated with higher price ranges, were observed price ranges in VTE treatment where DOACs proved to be economically more advantageous than warfarin, still requiring complete economic assessments.
\end{abstract}

Keywords: anticoagulants; costs and cost analysis; atrial fibrillation; venous thromboembolism.

\section{Anticoagulantes orais para tratamento de tromboembolismo venoso e fibrilação atrial não valvar: análise de custo}

\section{Resumo}

Objetivo: Analisar o custo direto total das terapias anticoagulantes indicadas para o tratamento crônico de pacientes com fibrilação atrial não valvar e o tratamento agudo de tromboembolismo venoso (TEV) na perspectiva de um hospital terciário de ensino e do Sistema Único de Saúde (SUS). Métodos: Para isso, foi realizada a revisão dos esquemas de tratamento que incluíam anticoagulantes orais com base em diretrizes nacionais e internacionais. Os dados de custos foram extraídos e realizada a simulação dos custos da terapia farmacológica e exames de monitoramento de metas terapêuticas. Foram definidos horizontes temporais de 365 dias para FA e 90 dias para TEV. Resultados: O custo do tratamento de TEV por 90 dias foi de: rivaroxabana (USD \$82,96 a USD \$156,15), apixabana (USD \$110,25 a USD \$123,11), edoxabana (USD \$106,56 a USD \$265,15), dabigatrana (USD \$150,71 a USD \$249,98) e varfarina (USD $\$ 54,94$ a USD \$159,66). Já para FA os custos do tratamento anual foram de: rivaroxabana (USD \$270,35 a USD \$508,89), apixabana (USD $\$ 414,86$ a USD \$463,26), edoxabana (USD \$402,41 a USD \$477,78), dabigatrana (USD \$414,86 a USD \$416,24) e varfarina (USD \$20,03 a USD \$43,54). Conclusão: A varfarina se mostrou com o menor custo de tratamento para ambas as comorbidades. Contudo, embora os anticoagulantes diretos orais (DOACs) estejam sempre associados a faixas de preços mais elevadas, foram observadas faixas de preço no tratamento de TEV nas quais os DOACs se mostraram economicamente mais vantajosos do que a varfarina, sendo ainda necessária a realização de avaliações econômicas completas.

Palavras-chave: anticoagulantes; custos e análise de custo; fibrilação atrial; tromboembolia venosa. 


\section{Introduction}

Anticoagulant therapy, the use of which is essential to control thrombotic risks in patients with Atrial Fibrillation (AF) or even as a treatment for dissolving thrombi in deep veins or pulmonary emboli, has been a major discussion topic currently. For a long time, this therapy has been limited to the use of vitamin $\mathrm{K}$ antagonists, but in recent years the use of direct oral anticoagulants (DOACs) has been promoted..$^{1-4}$

For the choice of therapy, it must be taken into account that there is no totally safe anticoagulant with regard to bleeding, and the risk must be assessed in the choice of treatment. There are several possible lines of treatment, taking into account the benefits and disadvantages of each. ${ }^{4,5}$

Much has been studied about the efficacy and safety outcomes among these drugs. It is known that, although vitamin K antagonists are effective, they require frequent monitoring because they have a narrow therapeutic window, since they significantly interact with food and medications and because of their complex dosage, which can culminate in low adherence. ${ }^{6-8}$ The study by Mohan et al. (2019) shows that lower doses and duration of therapy significantly improve adherence to anticoagulant treatment, and that rivaroxaban has shown greater acceptance compared to other direct oral anticoagulants. ${ }^{9}$ In addition to that, DOACs have an advantage for having demonstrated effectiveness and safety in view of the risk of bleeding and less interactions with food and medications. However, the risk for the recurrence of venous thromboembolism (VTE) is similar among the classes of oral anticoagulants. ${ }^{10}$

Another important aspect to be pointed out in the choice of the therapy employed is the cost. Cost analysis is a tool that assists the actors in the care and management process in decisionmaking, enabling the comparison of costs associated with the rationalization of expenses and clinical efficiency. ${ }^{11}$ Several studies comparing costs between oral anticoagulant therapies point to a saving of resources with the use of DOACs, since the use of these medications reduces the risk of bleeding and, consequently of readmissions due to these complications, and there is no need for routine monitoring. In addition to that, there is evidence of efficacy favorable to these medications. ${ }^{12-14}$

Given the potential advantages regarding the use of DOACs, this study aimed to analyze the total direct cost of anticoagulant therapies indicated for the chronic treatment of patients with nonvalvular AF and the acute treatment of VTE from the perspective of a tertiary teaching hospital in the city of Curitiba- Paraná and of the Unified Health System (Sistema Único de Saúde, SUS).

\section{Methods}

This is a health cost analysis study that, according to the Brazilian guideline for economic evaluations, corresponds to the "partial economic assessment, in the scope of health, which considers only the costs of using technology". ${ }^{15}$

For this, a review of all treatment regimens that included oral anticoagulants was carried out based on national and international guidelines. The search was complemented with a review of the UpToDate database and package inserts of the reference medications. The review of anticoagulant therapy regimens for $\mathrm{AF}$ was based on the guideline of the European Society of Cardiology (ESC) published in 2020, ${ }^{1}$ the guideline of the
American College of Cardiology/American Heart Association Task Force on Practice Guidelines and the Heart Rhythm Society (AHA) ACC/HRS) updated in 20192,3 and in the II Brazilian Guidelines on Atrial Fibrillation published in $2016 .{ }^{19}$ The topic of each medication in the databases of UpToDate in the year $2020^{26-30}$ and the package insert for the reference medications were also reviewed. ${ }^{21-25}$ VTE treatment regimens were reviewed in two stages: for the treatment of pulmonary thromboembolism (PTE), the bases were the European Society of Cardiology (ESC) guideline published in 2019 ${ }^{16}$, the Pulmonary Embolism Guideline published in 2004 by Brazilian Society of Cardiology ${ }^{18}$ and the Recommendations for the management of pulmonary thromboembolism published in 2010 in the Brazilian Journal of Pulmonology (SBPT). ${ }^{20}$ For the treatment of deep vein thrombosis (DVT), the European Society of Cardiology (ESC) guideline published in $2018^{17}$ and the document entitled Project Guidelines: Deep Vein Thrombosis: Diagnosis and Treatment, published by the Brazilian Society of Angiology and Vascular Surgery (Sociedade Brasileira de Angiologia e de Cirurgia Vascular, SBACV) in 2015 were reviewed. ${ }^{5}$ The topic of each medication was also reviewed in the UpToDate databases in the year $2020^{26-30}$ as well as the package inserts of the reference medications..$^{21-25}$ For the treatment regimens without fixed doses, such as the initial dose of warfarin or the mean weight for calculating the dose of enoxaparin, as well as the frequency of INR collections, an expert panel was consulted using an electronic form.

The anticoagulant therapy regimens for AF and VTE summarized based on the aforementioned are described in Table 1. Warfarin was the only representative of the class of vitamin $\mathrm{K}$ antagonists, while the DOACs contemplated were apixaban, dabigatran, edoxaban and rivaroxaban. Due to the need for complementary parenteral therapy in the treatment of VTE, the unit costs of the Enoxaparin medication, representative of the low molecular weight heparin category standardized at the institution, were collected. No costs were simulated with unfractionated heparin due to the report of disuse for this indication, according to the expert panel.

The cost data from the hospital's perspective were extracted referring to the last purchase of standardized items at the institution, between the months of July and December 2020. The conversion to the currency in the United States, the Dollar (USD), was made based on the quotation on the date of the last purchase, and was also expressed in the Brazilian currency, the Real (R\$). From the perspective of the SUS, for the Medication Market Regulation Chamber (Câmara de Regulação do Mercado de Medicamentos, CMED) database, the value referring to the Maximum Selling Price to the Government (Preço Máximo de Venda ao Governo, PMVG) of $18 \%$ was used, according to the Tax on the Circulation of Goods and Services (Imposto sobre Circulação de Mercadorias e Serviços, ICMS) rate of the state of Paraná.

The costs related to the Price Panel (PP) database, which relates to public procurement data and information approved in the Federal Government Procurement System (COMPRASNET), were collected through an electronic address (https://paineldeprecos. planejamento.gov.br/) consulted in the month of December 2020. For both databases, unit costs related to treatments were used with the maximum, minimum and median values calculated for each item.

The cost of the monitoring test of time and activity of prothrombin (TAP) was extracted from the SUS System of Table of Procedures, Medications and OPM (SIGTAP), an examination that allows determining the international normalized ratio (INR), for assessment of the therapeutic target of the vitamin $\mathrm{K}$ antagonist anticoagulants. 
Table 1. Description of the treatment regimens for $A F^{2}$ and $V T E^{3}$ in adult patients

\begin{tabular}{|c|c|c|c|c|}
\hline & Medication & INR $^{1}$ & Description & Time horizon \\
\hline \multirow{4}{*}{$\mathrm{AF}^{2,4}$} & Warfarin & $2.0-3.0$ & 5 mg every $24 h$ & \multirow{4}{*}{365 days } \\
\hline & Apixaban & $N A^{6}$ & $5 \mathrm{mg}$ every $12 \mathrm{~h}$ & \\
\hline & Dabigatran & $N A^{6}$ & 150 mg every $12 \mathrm{~h}$ & \\
\hline & Edoxaban & $N A^{6}$ & $60 \mathrm{mg}$ every $24 \mathrm{~h}$ & \\
\hline \multirow{5}{*}{ TEV $^{3,4}$} & Warfarin + LMWH ${ }^{5}$ & $2.0-3.0$ & $\begin{array}{l}\text { LMWH }{ }^{5} \text { in the first } 5 \text { days or until reaching } \\
\text { therapeutic target } \\
+ \\
\text { Warfarin } \\
5 \text { mg every } 24 \mathrm{~h}\end{array}$ & \multirow{5}{*}{$\begin{array}{l}3 \text { months } \\
\text { (90 days) }\end{array}$} \\
\hline & Apixaban & $N A^{6}$ & $\begin{array}{l}10 \mathrm{mg} \text { every } 12 \mathrm{~h} \text { for } 7 \text { days } \\
\text { followed by } 5 \mathrm{mg} \text { every } 12 \mathrm{~h}\end{array}$ & \\
\hline & Dabigatran + LMWH ${ }^{5}$ & $N A^{6}$ & $\begin{array}{l}\text { LMWH }{ }^{5} \text { in the first } 5 \text { days or until reaching } \\
\text { therapeutic target } \\
+ \\
\text { Dabigatran } \\
150 \text { mg every } 12 \mathrm{~h}\end{array}$ & \\
\hline & Edoxaban + LMWH & $N A^{6}$ & $\begin{array}{l}\text { LMWH }{ }^{5} \text { in the first } 5 \text { days or until reaching } \\
\text { therapeutic target } \\
+ \\
\text { Edoxaban } \\
>60 \mathrm{~kg}: 60 \mathrm{mg} \text { every } 24 \mathrm{~h} \\
\leq 60 \mathrm{~kg}: 30 \mathrm{mg} \text { every } 24 \mathrm{~h}\end{array}$ & \\
\hline & Rivaroxaban & $N A^{6}$ & $\begin{array}{l}15 \text { mg every } 12 \mathrm{~h} \text { for } 21 \text { days } \\
\text { followed by } 20 \text { mg every } 24 \mathrm{~h}\end{array}$ & \\
\hline
\end{tabular}

1INR: International Normalized Ratio. ${ }^{2}$ AF: Atrial Fibrillation. ${ }^{3}$ VTE: Venous Thromboembolism. ${ }^{4}$ The treatments were reviewed with the following guidelines as basis: AF- ESC (2020) ${ }^{1}$ AHA (2019/2014) $)^{2,3}$; SBC (2016) $)^{18}$; UpToDate $(2020)^{25-29}$ and package inserts of the reference medications ${ }^{20-24}$; VTE- ESC $(2019)^{15}$, SBC $(2004)^{17}$ and SBTP $(2010)^{19}$ for TEP and ESC $(2018)^{16}$ and SBACV $(2015)^{5}$ for VTP; UpToDate $(2020)^{25-29}$ and package inserts of the reference medications ${ }^{20-24} .{ }^{5}$ LMWH: Low Molecular Weight Heparin. ${ }^{6}$ NA: Not Applicable.

The costs related to the treatments were collected in a unitary manner and expressed by item and presentation of each medication (Table 2). The cost simulations were performed with the maximum, minimum and median values according to the treatment scheme in Table 1 . These were counted with the aid of the Microsoft Excel tool, considering adult patients with a weight range between $60 \mathrm{~kg}$ and $80 \mathrm{~kg}$ and time horizons of 365 days for AF and 90 days for VTE. There were no divergences in treatment in the reviewed guidelines for this population.

In this analysis, only the costs of the pharmacological treatment and laboratory tests used to control the therapeutic goals were considered. The results were expressed in the currency of the United States, the Dollar (USD), according to the conversion made by the Brazilian Central Bank on 12/01/2020 (conversion rate of 0.1894), with the exception of the costs in the perspective of the hospital, based on the quotation of the date of the last purchase. They were also expressed in Brazilian currency, the Real (R\$).

\section{Results}

The DOACs apixaban, edoxaban and dabigatran presented a unique value according to the CMED reference due to the validity of a patent, and still do not have a purchase value in the hospital because they are not standardized items in the institution. For enoxaparin, warfarin and rivaroxaban, the median price of all presentations available in the databases, whether reference medications, generic drugs or similar, was calculated.
Table 2. Unit costs of the medications and examination for treatment of $\mathrm{AF}^{1}$ and $\mathrm{VTE}^{2}$

\begin{tabular}{|c|c|c|c|}
\hline $\begin{array}{l}\text { Medication } \\
\text { (by presentation) }\end{array}$ & $\begin{array}{l}\text { Hospital } \\
\text { USD } \\
\text { R\$ }\end{array}$ & $\begin{array}{l}\text { CMED } \\
\text { USD } \\
\text { R\$ } \\
\text { Median }\left(P_{25} ; P_{75}\right)\end{array}$ & $\begin{array}{l}\mathrm{PP}^{5} \\
\text { USD } \\
\mathrm{R} \$\end{array}$ \\
\hline Warfarin 5 mg & $\begin{array}{l}0.04 \\
0.22\end{array}$ & $\begin{array}{l}0.07(0.06 ; 0.06) \\
0.37(0.32 ; 0.32)\end{array}$ & $\begin{array}{l}0.03 \\
0.17\end{array}$ \\
\hline Apixaban 5 mg & $\mathrm{NSM}^{3}$ & $\begin{array}{l}0.57 \\
3.00\end{array}$ & $\begin{array}{l}0.63 \\
3.35\end{array}$ \\
\hline Dabigatran 150 mg & $\mathrm{NSM}^{3}$ & $\begin{array}{l}0.57 \\
3.01\end{array}$ & $\begin{array}{l}0.57 \\
3.00\end{array}$ \\
\hline Edoxaban $30 \mathrm{mg}$ & $\mathrm{NSM}^{3}$ & $\begin{array}{l}0.65 \\
3.46\end{array}$ & $\begin{array}{l}0.65 \\
3.41\end{array}$ \\
\hline Edoxaban $60 \mathrm{mg}$ & $\mathrm{NSM}^{3}$ & $\begin{array}{l}1.31 \\
6.91\end{array}$ & $\begin{array}{l}1.10 \\
5.82\end{array}$ \\
\hline Rivaroxaban 15 mg & $\begin{array}{l}1.38 \\
7.36\end{array}$ & $\begin{array}{l}1.14(1.01 ; 1.14) \\
6.01(5.33 ; 6.02)\end{array}$ & $\begin{array}{l}1.33 \\
7.04\end{array}$ \\
\hline Rivaroxaban 20 mg & $\begin{array}{l}1.38 \\
7.36\end{array}$ & $\begin{array}{l}1.14(1.01 ; 1.14) \\
6.01(5.33 ; 6.02)\end{array}$ & $\begin{array}{l}1.32 \\
6.99\end{array}$ \\
\hline Enoxaparin $60 \mathrm{mg}$ & $\begin{array}{l}4.73 \\
25.30\end{array}$ & $\begin{array}{l}10.83(10.51 ; 12.59) \\
57.17(55.47 ; 66.45)\end{array}$ & $\begin{array}{l}4.84 \\
25.56\end{array}$ \\
\hline Enoxaparin $80 \mathrm{mg}$ & $\begin{array}{l}6.00 \\
31.00\end{array}$ & $\begin{array}{l}13.99(13.99 ; 14.45) \\
73.89(73.84 ; 76.27)\end{array}$ & $\begin{array}{l}5.12 \\
27.03\end{array}$ \\
\hline Exam & SIGTAP 6 & & \\
\hline$I N R^{7}$ & $\begin{array}{l}0.52 \\
2.73\end{array}$ & & \\
\hline
\end{tabular}

${ }^{1}$ AF: Atrial Fibrillation. ${ }^{2}$ VTE: Venous Thromboembolism. ${ }^{3} \mathrm{NSM}$ - Non-Standardized Medication. ${ }^{4}$ CMED: Câmara de Regulação do Mercado de Medicamentos (Medication Market Regulation Chamber). ${ }^{5}$ PP: Pricing Panel. ${ }^{6}$ SIGTAP ${ }^{7}$ International Normalized Ratio Note: The values referring to the PP database have already been extracted as median; there is no availability of dispersion measures such as IQR in the database. 
Rivaroxaban varied its unit price between USD 0.74 and USD 1.14 for the CMED reference, and between USD 1.02 and USD 50.90 in the $20 \mathrm{mg}$ presentation and from USD 1.08 to USD 41.67 in the $15 \mathrm{mg}$ presentation for the PP reference. Warfarin, on the other hand, varied its price between USD 0.05 and USD 0.10 for the CMED reference and between USD 0.02 and USD 0.17 for the PP reference. Taking into account the calculation of the enoxaparin dose by weight, a variation of unit price from USD 10.37 to USD 11.06 was found by the CMED reference and from USD 3.49 to USD 9.47 by the PP reference for the $60 \mathrm{mg}$ presentation, and from USD 13.80 to USD 14.73 for the CMED reference and USD 4.64 to USD 8.90 for the PP reference for the $80 \mathrm{mg}$ presentation.

The cost of VTE treatment for 90 days (Table 3) ranged from USD 54.71 to USD 159.66 with warfarin, from USD 110.25 to
USD 123.11 with apixaban, from USD 150.71 to USD 249.98 with dabigatran, from USD 106.56 to USD 265.15 with edoxaban and from USD 82.96 to USD 154.77 with rivaroxaban. Assessing the price ranges, scenarios can be noticed in which the DOACs prove to be more economically advantageous compared to warfarin.

For the annual treatment of AF (Table 3), the costs of annual treatment ranged from USD 20.03 to USD 43.54 with warfarin, from USD 414.86 to USD 463.26 with apixaban, from USD 414.86 to USD 416, 24 with dabigatran, from USD 402.41 to USD 477.78 with edoxaban and from USD 270.35 to USD 503.70 with rivaroxaban. Contrary to what was seen for the treatment of VTE, treatment with DOAC proved to be more expensive.

Table 3. Costs of annual $\mathrm{AF}^{4}$ treatment and in 90 days for $\mathrm{VTE}^{5}$ per treatment scheme and price basis

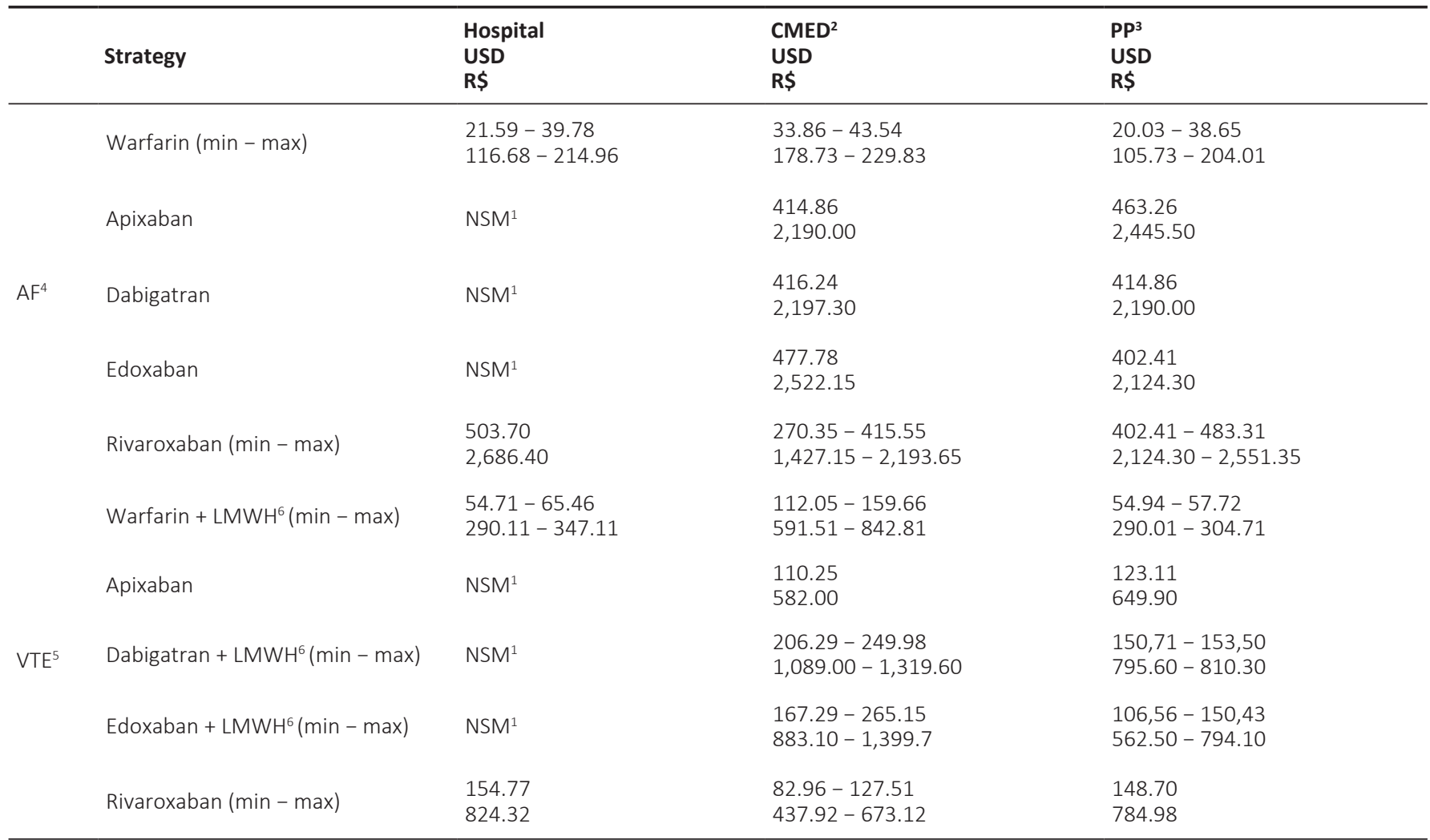

${ }^{1}$ NSM- Non-Standardized Medication. ${ }^{2}$ CMED: Câmara de Regulação do Mercado de Medicamentos (Medication Market Regulation Chamber). ${ }^{3}$ PP: Pricing Panel. ${ }^{4}$ AF: Atrial Fibrillation. ${ }^{5} \mathrm{VTE}$ : Venous Thromboembolism. ${ }^{6}$ LMWH: Low Molecular Weight Heparin.

\section{Discussion}

The results of the cost simulation demonstrated that, comparing only the pharmacological treatment, the DOACs present a significant and unfavorable acquisition difference in the prolonged treatment. However, a study by Piedade et al 2017, comparing the budgetary impact for the treatment of VTE from the perspective of the Supplementary Health System, demonstrated the potential for reducing total costs with the introduction of rivaroxaban, a result expressed mainly by the reduction in hospitalization time when compared to warfarin. ${ }^{11}$

This effect can be explained by the action mechanism of anticoagulants. Warfarin exerts its effect by reducing the synthesis of clotting factors activated by decreasing vitamin $\mathrm{K}$ reserves. The main enzyme responsible for the metabolization of this drug is CYP2C9, so that the factors that modulate its expression and its activity will influence the antithrombotic response. The interaction mechanism of drugs and food with warfarin is not exclusively dependent on its metabolization, and other factors, such as increased intake of foods rich in vitamin $\mathrm{K}$ or changes in the absorption of the pharmaceutical form, they can lead to a reduction or potentiation of its effect. It is also known that most antibiotics, antifungals, anti-depressants, antiplatelet agents and anti-inflammatories interact significantly with warfarin. Consequently, attentive monitoring of the therapeutic target must 
be carried out when the combination of these drugs is necessary. In addition to that, some foods, teas and natural extracts have their use discouraged during treatment due to the lability of the therapeutic target. ${ }^{8,31-34}$

The need for this additional care when using vitamin $\mathrm{K}$ antagonists against DOACs ends up adding up to the cost of global treatment due to the periodicity of monitoring INR and to the increased likelihood of unfavorable outcomes. In addition to the disadvantage in the sum of direct costs, a study by Van Walraven et al 2006 showed that patients spend, on average, more than one third of their time outside the therapeutic range, and that this time in the therapeutic range reduced further in the studies in which the patients were followed-up in the community when compared to randomized controlled trials, ${ }^{35}$ resuming the discussion that the instability in the control of the therapeutic goals contributes to this unfavorable safety profile of Warfarin.

In addition, it is already evident that the effectiveness of the DOACs compared to warfarin is equivalent. ${ }^{6}$ However, realworld studies point to superior effectiveness and safety, with a lower incidence of stroke and a significant reduction in the risk of bleeding compared to warfarin, and even differences between representatives of the class. $6,8,40,41$

Not least important, the patient's adherence to the anticoagulant therapy is a decisive factor for obtaining a safe and effective therapy. There are several factors that contribute to the failure of this process, including dosage complexity, the need for monitoring and the cost of the therapy. ${ }^{9}$ The main disadvantage of the DOACs is their higher direct costs, which in many scenarios favor non-adherence due to difficulties in accessing the therapy. However, some studies suggest that there can be an improvement in adherence despite the high cost, since the DOACs present easy dosage and there is no need for constant monitoring. ${ }^{37,38}$ In addition to this, another limiting point in this class is the low availability of an antidote in cases of severe bleeding; the study by Toorop et al 2020 shows that more than half of the patients rate this as an important factor in treatment satisfaction. ${ }^{42}$ Another study showed that there was no significant difference in adherence compared to warfarin. ${ }^{38}$ The use of DOACs at the expense of warfarin is still a hotly debated issue due to its multiple determining factors, for example, considering the context of $\mathrm{AF}$, anticoagulant therapy is indicated purely for the prevention of thrombotic events, so it does not treat symptoms and is especially vulnerable to non-adherence. In addition to that, the process of adhering to the anticoagulant therapy has proved to be a challenge, regardless of the medication used. ${ }^{37}$

This study has some limitations. The only costs contemplated were those of the pharmacological treatment. This shows the simplified value of the treatment, allowing a direct comparison. When discussing the cost of global treatment, consideration must be given to all therapy interfering factors, which can increase the likelihood of an unwanted outcome during treatment. In addition to that, another limitation of this study was that it was not possible to evaluate measures of variability and dispersion such as interquartile range (IQR) in most data, since some medications only have one manufacturer due to the validity of a patent, and yet, the values withdrawn from the PP database have already been extracted as median, without the availability of these measures in the database.

\section{Conclusion}

Despite the advantages of direct anticoagulants over warfarin, such as ease of use, absence of need for monitoring and low potential for food/drug interactions, the high acquisition costs are disadvantageous. However, for the treatment of VTE, price ranges were observed in which the DOACs proved to be economically more advantageous than warfarin, adding only the costs of the pharmacological therapy.

This study was a partial economic assessment of direct medical costs, and the results obtained can support the conduction of complete economic assessments, such as cost-effectiveness studies, on the use of DOACs for better decision-making.

\section{Funding sources}

This research did not receive funding for its conduction.

\section{Collaborators}

I.C.D. Conception and project, data analysis and interpretation, and writing of the article. A.M.M. Data analysis and interpretation and relevant critical review of the intellectual content. H.H.B. Data analysis and interpretation and relevant critical review of the intellectual content.

\section{Conflicts of interest statement}

The authors declare that there are no conflicts of interest in relation to this article.

\section{References}

1. Hindricks G, Potpara, T, Dagres N, et al. 2020 ESC Guidelines for the diagnosis and management of atrial fibrillation developed in collaboration with the European Association of Cardio-Thoracic Surgery (EACTS). European Heart Journal. 2020;00:1125.

2. January CT, Wann LS, Calkins H, et al. 2019 AHA/ACC/ HRS focused update of the 2014 AHA/ACC/HRS guideline for the management of patients with atrial fibrillation: a report of the American College of Cardiology Foundation/ American Heart Association Task Force on Clinical Practice Guidelines and the Heart Rhythm Society. J Am Coll Cardiol 2019;74:104-132.

3. January CT, Wann LS, Alpert JS, et al. 2014 AHA/ACC/HRS guideline for the management of patients with atrial fibrillation: a report of the American College of Cardiology/American Heart Association Task Force on Practice Guidelines and the Heart Rhythm Society. J Am Coll Cardiol 2014;64:e1-76.

4. Witt DM, Clark NP, Vazquez SR. Venous Thromboembolism. In: Pharmacotherapy: A Pathophysiologic Approach. 10응 edição. United States of America: McGraw-Hill Education, 2017:912-986

5. Presti C, Miranda JR F. Projeto Diretrizes: Trombose Venosa Profunda Diagnóstico e Tratamento. SBCAV. 2015. 
6. Almutairi AR, Zhou L, Gellad WF, et al. Effectiveness and Safety of Non-vitamin K Antagonist Oral Anticoagulants for Atrial Fibrillation and Venous Thromboembolism: a systematic review and meta-analyses. Clinical Therapeutics. 2017;39(7):1456-1478.

7. Van der hulle T, Kooiman J, Den exter PL, et al. Effectiveness and safety of novel oral anticoagulants as compared with vitamin $\mathrm{K}$ antagonists in the treatment of acute symptomatic venous thromboembolism: a systematic review and meta-analysis. J Thromb Haemost. 2014; 12:320-8.

8. Holbrook AM, Pereira JA, Labiris R, et al. Systematic overview of warfarin and its drug and food interactions. Arch Intern Med. 2005;165:1095-1106.

9. Mohan A, Wanat MA, Abughosh SM. Medication taking behaviors in patients taking warfarin versus direct oral anticoagulants: a systematic review. Expert review of cardiovascular Therapy. 2019;17(6):427-434.

10. Kearon C, Aki EA, Ornelas J, et al. Antithrombotic Therapy for VTE Disease CHEST Guideline and Expert Panel Report. American College of Chest Physicians. 2016;149(2):315-352.

11. Packeiser PB, Resta DG. Farmacoeconomia: uma ferramenta para a gestão dos gastos com medicamentos em hospitais públicos. Infarma- Ciências Farmacêuticas. 2014; 26(4):215223.

12. Piedade $A D$, Paladini L, Kashiura $D$, et al. Análise econômica do tratamento de tromboembolismo venoso com rivaroxabana em comparação com enoxaparina seguida de varfarina sob a perspectiva do Sistema de Saúde Suplementar brasileiro. Brazilian Journal of Health Economics. 2017; 9(1):109121.

13. Diken A, Yalçinkaya A, Hanedan M, et al. Rivaroxaban vs. warfarin on extended deep venous thromboembolism treatment: A cost analysis. Phlebology. 2017:1-7.

14. Merli G, Hollander J, Lefebvre P, et al. Costs of hospital visits among patients with deep vein thrombosis treated with rivaroxaban and LMWH/warfarin. Journal of Medical Economics. 2015:12-22.

15. Brasil. DIRETRIZES METODOLÓGICAS: Diretriz de Avaliação Econômica. Ministério da saúde. 2014; 2: 134.

16. Konstantinides SV, Meyer G, Becattini C, et al. 2019 ESC Guidelines for the diagnosis and management of acute pulmonary embolism developed in collaboration with the European Respiratory Society (ERS). European Heart Journal. 2020; 41, 543603.

17. Mazzolail L, Aboyans V, Ageno W, et al. Diagnosis and management of acute deep vein thrombosis: a joint consensus document from the European Society of Cardiology working groups of aorta and peripheral vascular diseases and pulmonary circulation and right ventricular function. European Heart Journal. 2018; 39:4208-4218.

18. Volschan A, Caramelli B, Gottschall CAM, et al. Diretriz de Embolia Pulmonar. Arquivos Brasileiros de Cardiologia. 2004.83(1):1-8.

19. Magalhães LP, Figueiredo MJO, Cintra FD, et al. II Diretrizes Brasileiras de Fibrilação Atrial. Arquivos Brasileiros de Cardiologia. 2016.106(4):supl 2.
20. Martinez JAB, Kritski AL, Cruz AA, et al. Recomendações para o manejo da tromboembolia pulmonar. Brasília: J Bras Pneumol. 2010. 36(1):S1-S68

21. ELIQUIS ${ }^{\oplus}$ : apixabana. Liliana R. S. Bersan. Porto Rico: Wyeth Indústria Farmacêutica Ltda, 2020. Bula de remédio.

22. LIXIANA ${ }^{\circledR}$ : edoxabana. Pedro de Freitas Fiorante. São Paulo: Daiichi Sankyo Brasil Farmacêutica LTDA, 2018. Bula de remédio.

23. MAREVAN ${ }^{\circledR}$ : varfarina sódica. Marcia Weiss I. Campos. Rio de Janeiro: Farmoquímica S/A, 2014. Bula de remédio.

24. PRADAXA ${ }^{\oplus}$ : etexilato de dabigatrana. Ana Carolina Scandura Cardillo. Alemanha: Boehringer Ingelheim Pharma GmbH \& Co. KG, 2013. Bula de remédio.

25. XARELTO ${ }^{\circledR}$ : rivaroxabana. Dirce Eiko Mimura. Alemanha: Bayer S.A., 2013. Bula de remédio.

26. UpToDate. Apixaban: Drug information. Disponível em: $\quad<$ https://www.uptodate.com/contents/apixaban-drug-information?search=apixabana\&source=panel_search_result\&selectedTitle $=1 \sim 149 \&$ usage_type $=$ panel\&kp_tab=drug_general\&display_rank $=1>$ Acesso em: 18/08/2020a.

27. UpToDate. Dabigatran: Drug information. Disponível em: $\quad<$ https://www.uptodate.com/contents/dabigatran-drug-information?search=dabigatrana\&source=panel_search_result\&selectedTitle=1 146\&usage_type=panel\&kp_tab=drug_general\&display_rank=1> Acesso em: $18 / 08 / 2020 b$.

28. UpToDate. Edoxaban: Drug information. Disponível em: <https://www.uptodate.com/contents/edoxaban-drug-information?search=edoxaban\&source=panel_search_result\&selectedTitle=1 106\&usage_type=panel\&kp_tab=drug_general\&display_rank=1> Acesso em: 18/08/2020c.

29. UpToDate. Rivaroxaban: Drug information. Disponível em: $\quad<$ https://www.uptodate.com/contents/rivaroxaban-drug-information?search=rivaroxabana\&source=panel search_result\&selectedTitle $=1 \sim 148 \&$ usage type $=$ panel $\&$ kp_tab=drug_general\&display_rank $=1>$ Acesso em: $18 / 08 / 2020 d$.

30. UpToDate. Warfarin: Drug information. Disponível em: $<$ https://www.uptodate.com/contents/warfarin-drug-information?search=varfarina\&source=panel_search_result\&selectedTitle $=1 \sim 148 \&$ usage_type $=$ panel\&kp_tab=drug_general\&display_rank=1> Acesso em: 18/08/2020e.

31. Juurlink DN. Drug interactions with warfarin: what clinicians need to know. Canadian Medical Association Journal. 2007;177(4):369-371.

32. Greenblatt DJ, Von Moltke LL. Interaction of Warfarin With Drugs, Natural Substances, and Foods. The Journal Of Clinical Pharmacology. 2005;45(2):127-132.

33. Wells PS, Holbrook AM, Crowther NR, et al. Interactions of Warfarin with Drugs and Food. Annals Of Internal Medicine. 1994;121(9):676-683.

34. Teles JS, Fukuda EY, Feder D. Warfarin: pharmacological profile and drug interactions with antidepressants. Einstein (São Paulo). 2012;10(1):110-115. 
35. Van Walraven $C$, Jennings $A$, Oake $N$, et al. Effect of Study Setting on Anticoagulation Control. Chest, 2006;129(5):11551166.

36. Sharma M, Cornelius VR, Patel JP, et al. Efficacy and Harms of Direct Oral Anticoagulants in the Elderly for Stroke Prevention in Atrial Fibrillation and Secondary Prevention of Venous Thromboembolism. Circulation. 2015;132(3):194-204

37. Yao X, Abraham NS, Alexander GC, et al. Effect of Adherence to Oral Anticoagulants on Risk of Stroke and Major Bleeding Among Patients With Atrial Fibrillation. Journal Of The American Heart Association. 2016:5(2):3074

38. Lai YF, Neo JK, Cheen AHH, et al. Comparison of Medication Adherence and Treatment Persistence between New Oral Anticoagulant and Warfarin among Patients. Annals Academy of Medicine. 2016;45:12-17.

39. Patel SI, Cherington $C$, Scherber $R$, et al. Assessment of Patient Adherence to Direct Oral Anticoagulant vs Warfarin Therapy. The Journal of The American Osteopathic Association. 2017;117(1):7-15.

40. Gupta K,Trocio J, Keshishian A, et al. Real-World Comparative Effectiveness, Safety, and Health Care Costs of Oral Anticoagulants in Nonvalvular Atrial Fibrillation Patients in the U.S. Department of Defense Population. J Manag Care Spec Pharm, 2018;24(11):1116-1127.

41. Lip GYH, Keshishian A, Li X, et al. Effectiveness and Safety of Oral Anticoagulants Among Nonvalvular Atrial Fibrillation Patients: The ARISTOPHANES Study. Stroke. 2018;49(12):29332944.

42. Toorop MA, Rein NV, et al. Switching from vitamin K antagonists to direct oral anticoagulants: Treatment satisfaction and patient concerns. J Thromb Haemost. 2020;18:1390-1397. 